\title{
IMPLEMENTASI TECHNOLOGY ACCEPTANCE MODEL DALAM NIAT MEMBELI KEMBALI TIKET BIOSKOP ONLINE
}

\author{
Rahadian Prianata ${ }^{1}$ \\ Ni Wayan Sri Suprapti \\ Alit Suryani ${ }^{3}$ \\ ${ }^{1,2,3}$ Fakultas Ekonomi dan Bisnis Universitas Udayana (Unud), Bali, Indonesia \\ e-mail: rian.prianata@gmail.com
}

\begin{abstract}
ABSTRAK
Tujuan dari penelitian ini adalah untuk menjelaskan pengaruh computer self-efficacy, persepsi kemudahan penggunaan, persepsi kegunaan, dan sikap dalam membeli dan niat membeli kembali tiket bioskop pada situs MTix. Populasi penelitian ini adalah semua orang yang pernah membeli tiket bioskop menggunakan situs MTix dan jumlahnya tidak diketahui secara pasti. Teknik pengambilan sampel adalah dengan sampel purposive sampling dengan total responden 150 orang. Teknik pengumpulan data adalah dengan menggunakan teknik wawancara dan kuisioner dengan skala likert 5 pilihan jawaban 1 sampai 5. Data yang diperoleh dianalisis menggunakan alat analisis PLS (Partial Least Square). Hasil penelitian didapat bahwa computer self-efficacy berpengaruh positif dan signifikan terhadap persepsi kemudahan penggunaan. Persepsi kemudahan penggunaan berpengaruh positif dan signifikan terhadap sikap dalam membeli. Persepsi kemudahan penggunaan berpengaruh positif dan signifikan terhadap sikap dalam membeli. Persepsi kemudahan penggunaan berpengaruh positif dan signifikan terhadap persepsi kegunaan, dan sikap dalam membeli berpengaruh positif dan signifikan terhadap niat untuk membeli kembali.
\end{abstract}

Kata Kunci : Computer Self-Efficacy, Persepsi Kemudahan Penggunaan, Persepsi Kegunaan, Sikap dalam Membeli, dan Niat Membeli Kembali

\begin{abstract}
The purpose of this study was to clarify the effect of computer self-efficacy, perceived ease of use, perceived usefulness, and attitudes and repurchase intention on MTix cinema tickets on the site. The population of this study were all people who had purchased cinema tickets using the MTix site and the numbers were not known for certain.. The sampling technique in this study with purposive sampling. Indicators research counted 19 indicators with a total of 150 respondents. Data collection techniques in this study using interview and questionnaire. In the questionnaire using Likert scale data measurement scale with five possible answers 1 to 5. Data were analyzed using analysis tools PLS (Partial Least Square). Result is that computer self-efficacy and significant positive effect on the perceived ease of use. Perceived ease of use and significant positive effect on attitudes in buying. Perceived ease of use and significant positive effect on attitudes in buying. Perceived ease of use positive and significant effect on the perception of usefulness and attitude in buying a positive and significant effect on repurchase intention.
\end{abstract}

Keywords : Computer Self-Efficacy, Perceived Ease of Use, Perceived Usefulness, Purchasing Attitude, and Repurchase Intention 


\section{PENDAHULUAN}

Dewasa ini dalam kehidupan sehari-hari terutama di kota-kota besar seperti Denpasar banyak sekali masyarakat yang selalu disibukkan dengan rutinitas dan pekerjaan sehari-hari. Semua kesibukan ini menyebabkan banyak orang yang membutuhkan suatu sarana hiburan yang bisa melepas rasa stress dari pekerjaan yang dilakukan dengan melakukan hiburan menonton film di bioskop. Sejauh ini 21Cineplex memiliki jaringan bioskop terbanyak di Bali. Seiring perkembangan teknologi yang semakin canggih, 21Cineplex mulai membuat inovasi baru dengan mulai memberlakukan sistem pembelian tiket bioskop secara online melalui situs Mtix. Inovasi ini dilakukan oleh 21Cineplex karena seiring berjalannya waktu masyarakat sudah banyak yang mulai mengenal dan menggunakan teknologi internet seperti data yang didapat dari APJII (2014) dapat diketahui bahwa Kota Denpasar di Provinsi Bali dengan total jumlah populasi hingga 863 ribu jiwa memiliki jumlah pengguna internet yang terhitung tinggi yakni sejumlah 291 ribu jiwa dengan penetrasi pengguna internet sebesar 33,7 persen. Angka ini menunjukkan bahwa jumlah pengguna internet di Kota Denpasar merupakan jumlah pengguna internet tertinggi di wilayah Indonesia Tengah.

Semenjak sistem pembelian tiket bioskop online MTix ini diberlakukan, pihak bioskop menaruh harapan bahwa dengan adanya sistem ini mampu memberikan kemudahan pada para konsumen membeli tiket bioskop untuk film yang diminati. . Hal ini dilihat karena meningkatnya pengguna internet di Indonesia dan banyaknya situs-situs belanja online yang marak bermunculan 
seiring dengan perkembangan teknologi akan mampu menciptakan peluang meningkatnya kecenderungan masyarakat untuk membeli tiket bioskop secara online. Pembelian tiket bioskop secara online ini dapat menarik perhatian para konsumen karena adanya beberapa hal, diantaranya dalam melakukan pembelian tiket bioskop ini tiket akan lebih mudah diperoleh karena bisa melakukan pembelian kapan saja dan dimana saja. Sistem pembelian tiket bioskop online ini juga fleksibel dan efisien, sehingga para konsumen yang ingin menonton film tidak perlu lagi repot-repot antre untuk membeli tiket bioskop. Tetapi kenyataannya, berdasarkan hasil wawancara dengan beberapa pengguna situs banyak orang yang menganggap sistem dalam membeli tiket bioskop online pada situs MTix ini cukup rumit. Sebuah pra-riset dilakukan pada 26 orang yang pernah menggunakan situs MTix di wilayah Denpasar. Hasil survei menunjukkan sebanyak 16 orang lebih memilih membeli tiket dengan mengantre, sedangkan sisanya sejumlah 10 orang lebih memilih membeli tiket lewat online pada situs MTix. Dari total 26 responden ini telah dipastikan bahwa semua responden telah mengetahui situs MTix. Jadi dari hasil survei ini menunjukkan bahwa perilaku konsumen dalam membeli tiket Bioskop 21Cineplex ini cenderung para responden lebih memilih membeli tiket dengan mengantre daripada membeli tiket secara online pada situs MTix. Apa yang berbeda dalam penelitian ini adalah sejauh ini belum ada penelitian yang menerapkan pengaruh computer self-efficacy dan pengaruh Technology Acceptance Model (TAM) terhadap sektor pembelian tiket bioskop pada situs MTix, sehingga bisa dikatakan penelitian ini merupakan penelitian pembaruan. 
Adapun kendala dalam penggunaan situs MTix ini, seseorang yang diharapkan menggunakan situs ini tentu orang yang paham dan familiar terhadap komputer, atau bisa disebut dengan computer self-efficacy. Compeau \& Higgins (1995) memandang computer self-efficacy merupakan "persepsi individu dari kemampuannya untuk menggunakan komputer dalam pemenuhan tugas, bukannya mencerminkan keterampilan komponen sederhana”. Persepsi kemudahan penggunaan merupakan penentu utama yang mempengaruhi penerimaan teknologi tertentu. Persepsi kemudahan penggunaan didefinisikan sebagai konsentrasi upaya fisik dan mental yang pengguna harapkan untuk menerima ketika mempertimbangkan penggunaan teknologi yaitu sejauh mana sistem teknologi tertentu akan bebas dari upaya (Davis, 1989). Definisi tersebut juga didukung oleh Wibowo (2006) yang menyatakan bahwa persepsi tentang kemudahan penggunaan sebuah teknologi didefinisikan sebagai suatu ukuran dimana seseorang percaya bahwa teknologi tersebut dapat dengan mudah dipahami dan digunakan.

Persepsi kegunaan juga berperan dalam situs MTix ini. Persepsi kegunaan adalah suatu tingkatan dimana seseorang percaya bahwa suatu penggunaan teknologi tertentu akan meningkatkan prestasi kerja orang tersebut (Davis 1989: 320). Adamson \& Shine (2003) mendefinisikan persepsi kegunaan sebagai konstruk kepercayaan seseorang bahwa penggunaan sebuah teknologi tertentu akan mampu meningkatkan kinerja seseorang.

Menurut Piriyakul et al. (2015) menyatakan dalam penelitiannya yang membahas tentang transaksi bisnis internet bahwa sikap bisa timbul dari adanya 
keyakinan apabila suatu sistem itu mudah digunakan dan berguna. Logika yang sama diamati dalam karya Lim \& Ting (2012) yang dalam penelitiannya membahas perilaku konsumen dalam melakukan transaksi belanja online sebagai situs belanja online yang mampu menyediakan layanan yang bermanfaat bagi konsumen dan layanan yang tidak tersedia melalui belanja tradisional (misalnya perbandingan antara produk sekilas) akan dianggap berguna oleh konsumen, dan dengan demikian mengarah pada pengembangan sikap yang menguntungkan terhadap belanja online. Seperti pada penelitian Jang et al. (2011) mengenai dampak kualitas pelayanan dalam melakukan penjualan TV kabel terhadap niat membeli kembali konsumen, penelitian menunjukkan bahwa perusahaan harus mengambil inisiatif untuk meningkatkan niat pembelian kembali tidak hanya berfokus pada interaksi integratif antara kemudahan penggunaan sistem dan kegunaannya, tetapi juga jelas memahami kebutuhan kepuasan pelanggan agar bisa menimbulkan sikap positif dari para konsumen sehingga mampu menimbulkan niat konsumen untuk melakukan pembelian kembali dalam melakukan transaksi online.

Penelitian ini merupakan penelitian asosiatif yang bertujuan untuk : (1) untuk menjelaskan pengaruh computer self-efficacy terhadap persepsi kemudahan penggunaan pada situs Mtix 21Cineplex, (2) untuk menjelaskan pengaruh persepsi kemudahan penggunaan terhadap sikap dalam membeli tiket online pada situs Mtix 21Cineplex, (3) untuk menjelaskan pengaruh persepsi kemudahan penggunaan terhadap persepsi kegunaan pada situs Mtix 21Cineplex, (4) untuk menjelaskan pengaruh persepsi kegunaan terhadap sikap dalam membeli tiket 
online pada situs Mtix 21Cineplex, (5) untuk menjelaskan pengaruh sikap dalam membeli tiket online terhadap niat untuk membeli kembali tiket online pada situs Mtix 21Cineplex. Yusoff et al. (2009) mendapatkan hasil bahwa computer selfefficacy tingkat tinggi dalam menggunakan situs web pada umumnya mengindikasi bahwa seseorang akan memiliki tingkat kepercayaan yang lebih tinggi dalam menggunakan situs web tersebut terutama apabila seseorang tersebut mengetahui bahwa situs tersebut mudah untuk digunakan. Penelitian lain juga didapat oleh Kulviwat et al. (2007), menunjukkan bahwa sebuah hubungan yang kuat ditemukan antara computer self-efficacy dan persepsi kemudahan penggunaan. Ini berarti bahwa penilaian computer self-efficacy memiliki peran yang besar untuk konsumen dalam membentuk persepsi tentang seberapa cepat operasinya dapat dipelajari dan betapa sederhana dalam menggunakan sistem tersebut.

H1: computer self-efficacy berpengaruh positif dan signifikan terhadap persepsi kemudahan penggunaan situs tiket bioskop online

Menurut penelitian yang dilakukan oleh Yusoff (2012), menunjukkan bahwa kemudahan penggunaan antarmuka teknologi dan alat-alat di situs online yang penting dalam memprediksi sikap terhadap belanja online. Secara khusus, penelitian ini lebih jauh berpendapat bahwa konsumen hanya akan mengembangkan sikap yang menguntungkan terhadap belanja online jika situs belanja online yang mudah digunakan. Penelitian juga dilakukan oleh Jang et al. (2011), akan tetapi dalam penelitian ini menunjukkan hasil bahwa pengaruh persepsi kemudahan penggunaan tidak memiliki hasil yang positif terhadap sikap 
dalam membeli. Sehingga hasil mengindikasikan persepsi kemudahan penggunaan memerankan peran yang sepele dalam sikap membeli para konsumen dalam berbelanja online.

$\mathrm{H} 2$ : persepsi kemudahan penggunaan berpengaruh positif dan signifikan terhadap sikap dalam membeli tiket bioskop online

Penelitian yang dilakukan oleh Yusoff et al. (2009), menunjukkan bahwa adanya hubungan yang signifikan dan positif antara persepsi kemudahan penggunaan dan persepsi kegunaan. Hal ini menunjukkan bahwa jika seseorang menemukan bahwa situs ini mudah digunakan, maka akan lebih bersedia untuk menggunakannya untuk pencarian informasi. Penelitian lain juga dilakukan oleh Lim \& Ting, (2012), menunjukkan bahwa kemudahan penggunaan antarmuka teknologi dan alat-alat di situs memiliki pengaruh signifikan pada kegunaan konsumen yang dirasakan dari penggunaan situs online. Untuk konsumen, sejauh mana situs online yang dianggap mudah digunakan sangat mempengaruhi kegunaannya dirasakan dari penggunaan situs online.

H3: persepsi kemudahan penggunaan berpengaruh positif dan signifikan terhadap persepsi kegunaan situs tiket bioskop online

Temuan Alharbi et al. (2014) sebagai studi menunjukkan bahwa konsumen akan mengembangkan sikap yang menguntungkan terhadap produk dan I atau jasa yang dipercaya untuk memberikan manfaat yang cukup atau atribut menuju solusi dan sikap negatif terhadap orang-orang yang tidak memadai. Penelitian ini juga didukung oleh penelitian yang dilakukan oleh Yusoff et al. (2009) yang menunjukkan bahwa persepsi kegunaan secara signifikan 
berhubungan dengan sikap terhadap belanja online. Sikap positif terhadap belanja online adalah karena alasan bahwa konsumen merasa bahwa belanja online meningkatkan kinerja belanja konsumen dan produktivitas. Penelitian juga dilakukan oleh Suki et al. (2011), yang menunjukkan bahwa adanya hubungan positif antara persepsi kegunaan terhadap sikap seseorang. Hasil ini menyatakan bahwa persepsi kegunaan merupakan penentu utama dari perilaku dan niat si pengguna.

H4: persepsi kegunaan berpengaruh positif dan signifikan terhadap sikap dalam belanja tiket bioskop online

Berdasarkan penelitian yang dilakukan oleh Jang et al. (2011), menunjukkan bahwa adanya pengaruh positif dari sikap terhadap minat membeli kembali. Marketer perusahaan harus mengambil inisiatif untuk meningkatkan niat pembelian kembali tidak hanya berfokus pada interaksi integratif antara persepsi kemudahan penggunaan dan kegunaan, tetapi juga jelas memahami kebutuhan kepuasan pelanggan dan kepercayaan pelanggan. Penelitian lain juga dilakukan oleh Yunfan et al. (2012) menunjukkan dimana sikap dalam membeli memberikan pengaruh yang positif terhadap niat membeli kembali. Dimana dalam penelitian menunjukkan bahwa sikap membeli konsumen dimana para konsumen terkadang mengeluh tidak selalu buruk bagi niat pembelian kembali. penjual online harus sabar menerima keluhan dan mencoba untuk meningkatkan produk dan kualitas layanan.

H5: sikap dalam membeli tiket online berpengaruh positif dan signifikan terhadap niat untuk membeli kembali tiket bioskop online 
Berdasarkan kajian pustaka dan penelusuran terhadap sejumlah hasil-hasil studi empiris, maka disusun sebuah kerangka konseptual sebagai berikut :

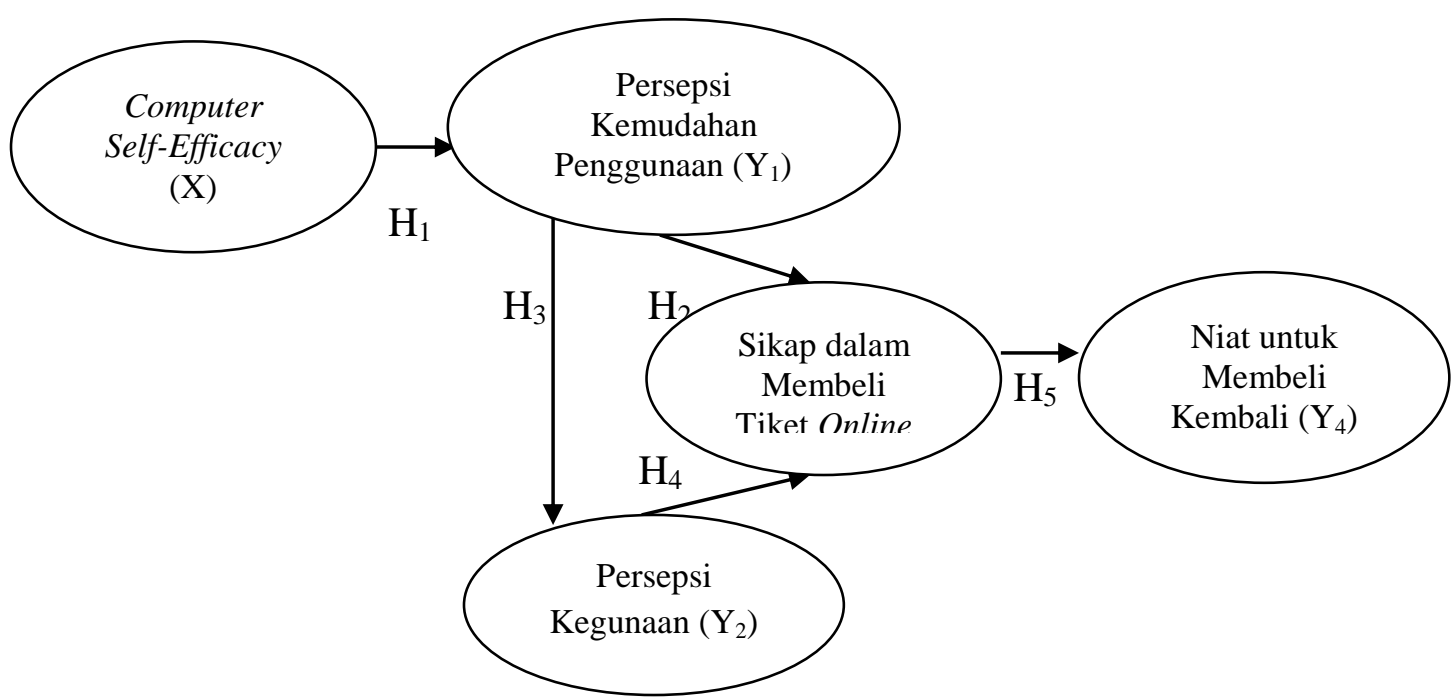

Gambar 1. Kerangka Konseptual Penelitian

\section{METODE PENELITIAN}

Penelitian ini merupakan penelitian asosiatif yang bertujuan untuk menjelaskan hubungan antara variabel computer self-efficacy, persepsi kemudahan penggunaan, persepsi kegunaan, sikap dalam membeli tiket online, dan minat untuk membeli kembali tiket online.

Ruang lingkup penelitian ini adalah niat konsumen dalam membeli kembali tiket bioskop melalui situs MTix yang diprediksi oleh beberapa variabel seperti computer self-efficacy, persepsi kemudahan penggunaan, persepsi kegunaan, dan sikap dalam membeli tiket bioskop secara online.

Penelitian ini menggunakan data kuantitatif dan data kualitatif. Data kuantitatif yang digunakan pada penelitian ini terdiri dari data pengguna internet di beberapa kota di Indonesia Tengah pada tahun 2014 dan data presentase konsumen yang membeli tiket online dan offline dalam pembelian tiket Bioskop 
21Cineplex di daerah Denpasar. Untuk data kualitatif, terdiri dari jenis kelamin responden, pendidikan responden, dan pendapat responden terhadap computer self-efficacy, persepsi kemudahan penggunaan, persepsi kegunaan, sikap dalam membeli tiket online, dan niat untuk membeli tiket online. Kedua jenis data itu diperoleh dari dua sumber, yaitu sumber data primer adalah para responden, dan sumber data sekunder adalah APJII.

Populasi penelitian ini adalah konsumen yang sudah tahu mengenai situs MTix dan sudah pernah membeli tiket bioskop secara online di situs MTix, dan jumlahnya tidak terbatas. Sampel penelitian ditentukan dengan metode non probability sampling dengan kriteria presponden harus berpendidikan minimal SMA atau sederajat, yang sering pergi menonton film dibioskop dan mengetahui situs MTix dan pernah membeli tiket bioskop online pada situs MTix dengan jumlah 150 responden.

Penelitian ini menggunakan kuisioner sebagai instrumen dalam mengumpulkan data dari responden. Kuisioner berisikan beberapa pernyataan mengenai identitas responden dan beberapa pernyataan mengenai variabel penelitian.

Data yang terkumpul dianalisis menggunakan statistik deskriptif dan statistik inferensial. Analisis deskriptif dilakukan dengan maksud untuk mengetahui karakteristik dan tanggapan responden terhadap item-item pertanyaan dalam kuisioner, sedangkan statistik inferensial digunakan untuk menguji hipotesis dengan menggunakan teknik analisis SEM-PLS. 


\section{HASIL DAN PEMBAHASAN}

Cineplex 21 merupakan salah satu perusahaan bioskop di Indonesia yang telah mengembangkan pelayanan pembelian tiket berbasis online. Layanan pembelian tiket berbasis online ini dikenal dengan sebutan MTix dan memiliki tujuan utama untuk memberikan pelayanan kenyamanan dan efisiensi kepada pelanggan ketika ingin membeli tiket pertunjukan film. M-Tix adalah layanan transaksi pembelian tiket jarak jauh (remote transaction) yang menawarkan pelanggan akan pembelian tiket bioskop tanpa harus mengantri dan dapat dilakukan dimana saja jika kebutuhan akan akses layanan tersebut terpenuhi. Terdapat tiga cara yang ditawarkan dalam melakukan pembelan tiket bioskop melalui situs MTix antara lain :

\section{Website}

Cara ini dilakukan oleh pelanggan dengan mengakses halaman website dan memilih judul film secara langsung. Para pelanggan dapat memilih waktu penayangan film dan tempat duduk yang diinginkan.

2. Call Center

Cara ini dilakukan oleh pelanggan dengan melakukan panggilan telepon dan kemudian pelanggan akan diberikan panduan pemesanan tiket bioskop.

3. Short Message Service (SMS)

Cara ini dilakukan oleh pelanggan dengan mengirimkan short message service ke nomor layanan yang telah ditentukan. 
Rahadian Prianata, Ni Wayan Sri Suprapti, Alit Suryani. Implementasi Technology Acceptance...

Berdasarkan jenis kelamin, responden didominasi oleh laki-laki sebanyak 52,7 persen, sedangkan sisanya perempuan sebesar 47,3 persen. Hal ini menunjukkan bahwa sebagian besar responden yang membeli tiket melalui M-Tix adalah laki-laki. Pada pengelompokkan berdasarkan pendidikan, mayoritas adalah kelompok responden dengan tingkat pendidikan S1 sebesar 77,3 persen, kemudian diikuti oleh SMA sebesar 11,3 persen, S2 sebesar 8,7 persen, dan D3 sebesar 2,7 persen.

Tabel 1.

Deskripsi Penilaian Responden Terhadap Indikator Variabel

\section{Pernyataan}

Rerata Skor Jawaban

Computer Self-Efficacy $(\mathbf{X})$

\begin{tabular}{lll}
\hline$\left(\mathrm{X}_{1}\right)$ & $\begin{array}{l}\text { Kemampuan membeli tiket } \text { online pada situs MTix tanpa } \\
\text { bantuan orang lain (Magnitude) }\end{array}$ & 4,01 \\
$\left(\mathrm{X}_{2}\right)$ & $\begin{array}{l}\text { Kemampuan melakukan pembelian tiket } \text { online pada situs } \\
\text { MTix dengan menggunakan panduan (Strength) }\end{array}$ & $\mathbf{4 , 0 5}$ \\
$\left(\mathrm{X}_{3}\right)$ & $\begin{array}{l}\text { Kemampuan melakukan pembelian tiket } \text { online pada situs } \\
\text { MTix dengan sistem yang berbeda (Generalibility) }\end{array}$
\end{tabular}

\begin{tabular}{lc}
\hline Rerata Konstruk Computer Self-Efficacy & 3,92 ( Baik ) \\
\hline Persepsi Kemudahan Penggunaan $\left(\mathbf{Y}_{1}\right)$ &
\end{tabular}

\begin{tabular}{|c|c|c|}
\hline$\left(Y_{1.1}\right)$ & $\begin{array}{l}\text { Saya merasa mudah dalam melakukan pembelian tiket melalui } \\
\text { situs Mtix }\end{array}$ & 4,33 \\
\hline$\left(\mathrm{Y}_{1.2}\right)$ & $\begin{array}{l}\text { Saya mudah memahami petunjuk yang disajikan dalam situs } \\
\text { Mtix }\end{array}$ & 4,10 \\
\hline$\left(\mathrm{Y}_{1.3}\right)$ & $\begin{array}{l}\text { Saya merasa fleksibel dalam melakukan pembayaran saat } \\
\text { membeli tiket bioskop secara online pada situs Mtix }\end{array}$ & 4,35 \\
\hline$\left(\mathrm{Y}_{1.4}\right)$ & $\begin{array}{l}\text { Saya merasa lebih terampil dalam berbelanja online setelah } \\
\text { bertransaksi membeli tiket online melalui situs Mtix }\end{array}$ & 3,77 \\
\hline \multicolumn{2}{|c|}{ Rerata Konstruk Persepsi Kemudahan Penggunaan } & 4,14 ( Mudah ) \\
\hline \multicolumn{3}{|c|}{ Persepsi Kegunaan $\left(\mathbf{Y}_{2}\right)$} \\
\hline$\left(\mathrm{Y}_{2.1}\right)$ & $\begin{array}{l}\text { Membeli tiket online melalui situs MTix merupakan cara yang } \\
\text { lebih praktis daripada membeli secara manual (antre) }\end{array}$ & 4,42 \\
\hline$\left(Y_{2.2}\right)$ & $\begin{array}{l}\text { Membeli tiket online melalui situs MTix merupakan cara yang } \\
\text { lebih cepat daripada membeli secara manual (antre) }\end{array}$ & 4,18 \\
\hline$\left(\mathrm{Y}_{2.3}\right)$ & $\begin{array}{l}\text { Membeli tiket online melalui situs MTix memberi banyak } \\
\text { pilihan bagi calon penonton sebelum mengambil keputusan }\end{array}$ & 4,22 \\
\hline$\left(\mathrm{Y}_{2.4}\right)$ & $\begin{array}{l}\text { Membeli tiket online pada situs MTix mampu meningkatkan } \\
\text { kemampuan saya dalam melakukan belanja online }\end{array}$ & 3,69 \\
\hline \multicolumn{2}{|c|}{ Rerata Konstruk Persepsi Kegunaan } & $\begin{array}{c}4,13 \\
\text { ( Bermanfaat ) }\end{array}$ \\
\hline
\end{tabular}

Sikap dalam Membeli ( $\left.\mathbf{Y}_{3}\right)$ 


\begin{tabular}{|c|c|c|}
\hline$\left(\mathrm{Y}_{3.1}\right)$ & $\begin{array}{l}\text { Saya merasa nyaman dengan melakukan pembelian tiket } \\
\text { bioskon secara online pada situs Mtix }\end{array}$ & 4,53 \\
\hline$\left(\mathrm{Y}_{3.2}\right)$ & $\begin{array}{l}\text { Saya merasa senang saat melakukan pembelian tiket bioskop } \\
\text { secara online pada situs Mtix }\end{array}$ & 4,24 \\
\hline$\left(\mathrm{Y}_{3.3}\right)$ & $\begin{array}{l}\text { Saya merasa melakukan pembelian tiket bioskop secara online } \\
\text { pada situs MTix merupakan ide yang bagus }\end{array}$ & 4,65 \\
\hline$\left(\mathrm{Y}_{3.4}\right)$ & $\begin{array}{l}\text { Saya merasa melakukan pembelian tiket bioskop secara online } \\
\text { pada situs MTix merupakan pilihan yang bijak }\end{array}$ & 4,18 \\
\hline \multicolumn{2}{|c|}{ Rerata Konstruk Sikap Dalam Membeli Tiket Online } & $\begin{array}{c}4,40 \\
\text { (Sangat Positif) }\end{array}$ \\
\hline \multicolumn{3}{|c|}{ Niat untuk Membeli Kembali $\left(\mathbf{Y}_{4}\right)$} \\
\hline$\left(\mathrm{Y}_{4.1}\right)$ & $\begin{array}{l}\text { Saya akan lebih sering menggunakan fasilitas situs MTix untuk } \\
\text { membeli tiket }\end{array}$ & 3,89 \\
\hline$\left(\mathrm{Y}_{4.2}\right)$ & $\begin{array}{l}\text { Saya akan berpindah membeli tiket dari cara manual (antre) ke } \\
\text { cara online melalui situs Mtix }\end{array}$ & 3,80 \\
\hline$\left(\mathrm{Y}_{4.3}\right)$ & $\begin{array}{l}\text { Saya akan selalu membeli tiket secara online melalui situs } \\
\text { MTix setiap akan menonton film }\end{array}$ & 3,67 \\
\hline$\left(\mathrm{Y}_{4.4}\right)$ & $\begin{array}{l}\text { Tidak akan kembali membeli tiket secara manual setelah ada } \\
\text { fasilitas online melalui MTix }\end{array}$ & 3,52 \\
\hline \multicolumn{2}{|c|}{ Rerata Konstruk Niat Untuk Membeli Kembali } & $\begin{array}{c}3,72 \\
\text { (Berniat) }\end{array}$ \\
\hline
\end{tabular}

Berdasarkan data pada tabel 2 dapat ditentukan rerata konstruk Computer Self-Efficacy adalah sebesar 3,92, maka dapat dinyatakan bahwa secara umum responden memiliki kepercayaan diri dalam mengoperasikan komputer ketika melakukan pembelian tiket bioskop online melalui situs M-Tix. Akan tetapi, hasil penilaian responden menunjukkan ada sebagian yang merasa belum terlalu mudah melakukan transaksi pada situs MTix. Hal ini dikarenakan masih ada pengguna situs merasa cukup sulit untuk memahami bagaimana melakukan transaksi dengan update sistem yang terbaru, sehingga mereka lebih memilih untuk melakukan transaksi pembelian tiket bioskop online dengan sistem yang lama pada situs MTix.

Selanjutnya, rerata konstruk persepsi kemudahan penggunaan adalah sebesar 4,14, maka dapat dinyatakan bahwa secara umum responden memiliki persepsi bahwa membeli tiket online melalui M-Tix itu mudah. Tapi pada hasil 
penelitian responden menunjukkan ada sebagian yang merasa bahwa pengoperasian pada situs MTix dianggap belum mampu untuk meningkatkan ketrampilan pengguna dalam berbelanja online. Hal ini dikarenakan ada penggguna yang merasa bahwa saat melakukan transaksi pada situs MTix belum mampu memberi pengaruh kepada para pengguna menjadi lebih terampil dalam berbelanja online setelah mendalami cara bertransaksi membeli tiket bioskop melalui situs MTix.

Rerata konstruk persepsi kegunaan adalah sebesar 4,13, maka dapat dinyatakan bahwa secara umum responden memiliki persepsi yang baik tentang manfaat membeli tiket bioskop secara online melalui M-Tix. Akan tetapi Hasil penelitian menunjukkan ada sebagian responden yang merasa saat melakukan transaksi pada situs MTix belum mampu meningkatkan kemampuan mereka dalam melakukan belanja online. Penyesuaian situs MTix dalam proses transaksi pembelian tiket bioskop online dengan situs beli tiket online lain tidak hanya meningkatkan ketrampilan para pengguna, tapi juga diharapkan mampu meningkatkan kemampuan para pengguna dalam melakukan belanja online. Para pengguna yang sebelumnya ragu-ragu untuk melakukan belanja online diharapkan mampu ditingkatkan kemampuannya dari melakukan transaksi pembelian tiket online pada situs MTix, sehingga para pengguna memiliki rasa percaya diri dalam melakukan transaksi belanja melalui situs online.

Lalu untuk rerata konstruk sikap dalam membeli tiket online adalah sebesar 4,40, maka dapat dinyatakan bahwa secara umum responden memiliki sikap yang sangat positif dalam membeli tiket bioskop online melalui M-Tix. 
Hasil penelitian responden menunjukkan ada beberapa yang merasa bahwa saat melakukan transaksi pembelian tiket bioskop pada situs MTix dinilai merupakan pilihan yang kurang bijak. Hal ini dikarenakan dalam melakukan transaksi sebagian dari para pengguna mengeluh karena sesekali dalam proses transaksi pembelian tiket terus mengalami kegagalan.

Selanjutnya rerata konstruk niat untuk membeli kembali adalah sebesar 3,72, maka dapat dinyatakan bahwa secara umum responden memiliki niat untuk membeli kembali tiket bioskop secara online melalui situs M-Tix. Hasil penelitian responden menunjukkan ada sebagian yang merasa ragu untuk tidak kembali membeli tiket secara manual setelah ada fasilitas online melalui situs MTix, karena adanya kegagalan dalam melakukan transaksi pembelian tiket pada situs MTix, membuat para pengguna yang awalnya ingin membeli secara online, terpaksa harus membeli tiket bioskop secara manual (antre).

Terdapat tiga kriteria dalam pengujian outer model pada PLS, yaitu menggunakan discriminant validity, composite reliability, dan convergent validity. Seperti tersaji pada Tabel 2.

Tabel 2.

Uji Validitas dan Reliabilitas

\begin{tabular}{llccc}
\hline Variabel dan Indikatornya & $\begin{array}{c}\text { Outer } \\
\text { Loadings *) }\end{array}$ & $\begin{array}{c}\text { AVE) } \\
*)\end{array}$ & $\begin{array}{c}\text { Composite } \\
\text { Reliability } \\
* *)\end{array}$ & $\begin{array}{c}\text { Cronbach } \\
\text { Alpha } \\
* *)\end{array}$ \\
\hline Computer Self-Efficacy $(\mathbf{X})$ & & & \\
\hline $\begin{array}{l}\text { Kemampuan membeli tiket } \text { online pada } \\
\text { situs MTix tanpa bantuan orang lain } \\
(\text { Magnitude) }\end{array}$ & 0,862 & & \\
$\begin{array}{l}\text { Kemampuan melakukan pembelian tiket } \\
\text { online pada situs MTix dengan } \\
\text { menggunakan panduan (Strength) }\end{array}$ & $\mathbf{0 , 8 6 3}$ & 0,679 & 0,863 & 0,808 \\
$\left(\mathrm{X}_{2}\right)$ & $\begin{array}{l} \\
\text { Kemampuan melakukan pembelian tiket } \\
\text { online pada situs MTix dengan sistem }\end{array}$ & 0,741 & & \\
\hline $\left.\mathrm{X}_{3}\right)$ &
\end{tabular}


yang berbeda (Generalibility)

\begin{tabular}{|c|c|c|c|c|c|}
\hline \multicolumn{6}{|c|}{ Persepsi Kemudahan Penggunaan $\left(\mathrm{Y}_{1}\right)$} \\
\hline$\left(Y_{1.1}\right)$ & $\begin{array}{l}\text { Saya merasa mudah dalam melakukan } \\
\text { pembelian tiket melalui situs Mtix }\end{array}$ & 0,772 & \multirow{4}{*}{0,586} & \multirow{4}{*}{0,850} & \multirow{4}{*}{0,781} \\
\hline$\left(\mathrm{Y}_{1.2}\right)$ & $\begin{array}{l}\text { Saya mudah memahami petunjuk yang } \\
\text { disajikan dalam situs Mtix }\end{array}$ & 0,784 & & & \\
\hline$\left(\mathrm{Y}_{1.3}\right)$ & $\begin{array}{l}\text { Saya merasa fleksibel dalam melakukan } \\
\text { pembayaran saat membeli tiket bioskop } \\
\text { secara online pada situs Mtix }\end{array}$ & 0,782 & & & \\
\hline$\left(Y_{1.4}\right)$ & $\begin{array}{l}\text { Saya merasa lebih terampil dalam } \\
\text { berbelanja online setelah bertransaksi } \\
\text { membeli tiket online melalui situs Mtix }\end{array}$ & 0,723 & & & \\
\hline \multicolumn{6}{|c|}{ Persepsi Kegunaan $\left(\mathrm{Y}_{2}\right)$} \\
\hline$\left(\mathrm{Y}_{2.1}\right)$ & $\begin{array}{l}\text { Membeli tiket online melalui situs MTix } \\
\text { merupakan cara yang lebih praktis } \\
\text { daripada membeli secara manual (antre) }\end{array}$ & 0,829 & \multirow{4}{*}{0,631} & \multirow{4}{*}{0,872} & \multirow{4}{*}{0,808} \\
\hline$\left(\mathrm{Y}_{2.2}\right)$ & $\begin{array}{l}\text { Membeli tiket online melalui situs MTix } \\
\text { merupakan cara yang lebih cepat } \\
\text { daripada membeli secara manual (antre) }\end{array}$ & 0,843 & & & \\
\hline$\left(\mathrm{Y}_{2.3}\right)$ & $\begin{array}{l}\text { Membeli tiket online melalui situs MTix } \\
\text { memberi banyak pilihan bagi calon } \\
\text { penonton } \\
\text { keputusan }\end{array}$ & 0,744 & & & \\
\hline$\left(\mathrm{Y}_{2.4}\right)$ & $\begin{array}{l}\text { Membeli tiket online pada situs MTix } \\
\text { mampu meningkatkan kemampuan saya } \\
\text { dalam melakukan belanja online }\end{array}$ & 0,757 & & & \\
\hline \multicolumn{6}{|c|}{ Sikap dalam Membeli $\left(\mathbf{Y}_{3}\right)$} \\
\hline$\left(\mathrm{Y}_{3.1}\right)$ & $\begin{array}{l}\text { Saya merasa nyaman dengan melakukan } \\
\text { pembelian tiket bioskop secara online } \\
\text { pada situs Mtix }\end{array}$ & 0,859 & \multirow{4}{*}{0,708} & \multirow{4}{*}{0,907} & \multirow{4}{*}{0,891} \\
\hline$\left(Y_{3.2}\right)$ & $\begin{array}{l}\text { Saya merasa senang saat melakukan } \\
\text { pembelian tiket bioskop secara online } \\
\text { pada situs Mtix }\end{array}$ & $\mathbf{0 , 8 7 8}$ & & & \\
\hline$\left(\mathrm{Y}_{3.3}\right)$ & $\begin{array}{l}\text { Saya merasa melakukan pembelian tiket } \\
\text { bioskop secara online pada situs MTix } \\
\text { merupakan ide yang bagus }\end{array}$ & 0,794 & & & \\
\hline$\left(\mathrm{Y}_{3.4}\right)$ & $\begin{array}{l}\text { Saya merasa melakukan pembelian tiket } \\
\text { bioskop secara online pada situs MTix } \\
\text { merupakan pilihan yang bijak }\end{array}$ & 0,834 & & & \\
\hline \multicolumn{6}{|c|}{ Niat untuk Membeli Kembali $\left(\mathbf{Y}_{4}\right)$} \\
\hline$\left(\mathrm{Y}_{4.1}\right)$ & $\begin{array}{l}\text { Saya akan lebih sering menggunakan } \\
\text { fasilitas situs MTix untuk membeli tiket }\end{array}$ & 0,775 & \multirow{4}{*}{0,676} & \multirow{4}{*}{0,893} & \multirow{4}{*}{0,759} \\
\hline$\left(\mathrm{Y}_{4.2}\right)$ & $\begin{array}{l}\text { Saya akan berpindah membeli tiket dari } \\
\text { cara manual (antre) ke cara online } \\
\text { melalui situs Mtix }\end{array}$ & 0,858 & & & \\
\hline$\left(\mathrm{Y}_{4.3}\right)$ & $\begin{array}{l}\text { Saya akan selalu membeli tiket secara } \\
\text { online melalui situs MTix setiap akan } \\
\text { menonton film }\end{array}$ & $\mathbf{0 , 8 6 3}$ & & & \\
\hline$\left(\mathrm{Y}_{4.4}\right)$ & $\begin{array}{l}\text { Saya tidak akan kembali membeli tiket } \\
\text { secara manual setelah ada fasilitas } \\
\text { online melalui Mtix }\end{array}$ & 0,788 & & & \\
\hline
\end{tabular}

Sumber: Hasil pengolahan data, 2017 
Pengujian inner model dilakukan dengan melihat nilai $R$-square yang merupakan uji goodness of fit model. Berdasarkan Tabel 2, model pengaruh computer self-efficacy terhadap persepsi kemudahan penggunaan memberikan nilai $R$-square sebesar 0,545 yang dapat diinterpretasikan bahwa variabilitas konstruk persepsi kemudahan penggunaan dapat dijelaskan oleh variabilitas konstruk computer self-efficacy sebesar 54,5 persen, sedangkan 44,5 persen dijelaskan oleh konstruk lain diluar yang diteliti. Selanjutnya, model pengaruh persepsi kemudahan penggunaan terhadap persepsi kegunaan memberikan nilai $R$ square sebesar 0,465 yang dapat diinterpretasikan bahwa variabilitas konstruk persepsi kegunaan dapat dijelaskan oleh variabilitas konstruk persepsi kemudahan penggunaan sebesar 46,5 persen, sedangkan 53,5 persen dijelaskan oleh konstruk lain diluar yang diteliti. Model pengaruh persepsi kemudahan penggunaan terhadap sikap dalam membeli tiket online memberikan nilai $R$-square sebesar 0,626 yang dapat diinterpretasikan bahwa variabilitas konstruk sikap dalam membeli tiket online dapat dijelaskan oleh variabilitas konstruk persepsi kemudahan penggunaan sebesar 62,6 persen sedangkan 37,4 persen dijelaskan oleh konstruk lain diluar yang diteliti. Terakhir, model pengaruh sikap dalam membeli tiket online terhadap niat untuk membeli kembali memberikan nilai $R$ square sebesar 0,557 yang dapat diinterpretasikan bahwa variabilitas konstruk niat untuk membeli kembali dapat dijelaskan oleh variabilitas konstruk sikap dalam membeli tiket online sebesar 55,7 persen sedangkan 44,3 persen dijelaskan oleh konstruk lain diluar yang diteliti. Selain itu, secara keseluruhan konstruk endogen memiliki nilai $R$-square di atas 0,33 yang mengindikasikan bahwa variabel laten 
independen memiliki pengaruh yang cukup baik atau moderat terhadap variabel laten dependen.

Tabel 3.

R-square

\begin{tabular}{lc}
\hline \multicolumn{1}{c}{ Konstruk } & R-Square \\
\hline Persepsi Kemudahan Penggunaan $\left(\mathrm{Y}_{1}\right)$ & 0,545 \\
Persepsi Kegunaan $\left(\mathrm{Y}_{2}\right)$ & 0,465 \\
Sikap Dalam Membeli Tiket Online $\left(\mathrm{Y}_{3}\right)$ & 0,626 \\
Niat Untuk Membeli Kembali $\left(\mathrm{Y}_{4}\right)$ & 0,557 \\
\hline
\end{tabular}
Sumber: Hasil pengolahan data, 2017

Untuk mengukur seberapa baik nilai observasi dihasilkan oleh model dan juga estimasi parameternya, maka perlu menhitung $Q$-square sebagai berikut:

$$
\begin{aligned}
\mathrm{Q}^{2} & =1-\left(1-\left(\mathrm{R}_{1}\right)^{2}\right)\left(1-\left(\mathrm{R}_{2}\right)^{2}\right)\left(1-\left(\mathrm{R}_{3}\right)^{2}\right)\left(1-\left(\mathrm{R}_{4}\right)^{2}\right) \\
& =1-(1-0,545)(1-0,465)(1-0,626)(1-0,557) \\
& =1-(0,455)(0,535)(0,374)(0,443) \\
& =1-0,040331141 \\
& =0,959668859
\end{aligned}
$$

Nilai $\mathrm{Q}^{2}$ memiliki berada pada rentang $0<\mathrm{Q}^{2}<1$, dimana semakin mendekati 1 berarti model semakin baik. Dengan demikian, dari hasil perhitungan

\begin{tabular}{|c|c|c|c|}
\hline Konstruk & Koef. Korelasi & $t$ Statistics & Keterangan \\
\hline $\begin{array}{l}\text { Computer } \quad \text { Self-Efficacy } \\
\text { Kemudahan Penggunaan }\left(\mathrm{Y}_{1}\right)\end{array}$ & 0,738 & 12,746 & Signifikan \\
\hline $\begin{array}{l}\text { Persepsi Kemudahan Penggunaan }\left(\mathrm{Y}_{1}\right) \rightarrow \text { Sikap } \\
\text { Dalam Membeli Tiket Online }\left(\mathrm{Y}_{3}\right)\end{array}$ & 0,465 & 5,367 & Signifikan \\
\hline $\begin{array}{lcc}\text { Persepsi } & \text { Kemudahan } & \text { Penggunaan } \\
\left(\mathrm{Y}_{1}\right) \rightarrow \text { Persepsi Kegunaan }\left(\mathrm{Y}_{2}\right) & \end{array}$ & 0,682 & 10,742 & Signifikan \\
\hline $\begin{array}{l}\text { Persepsi Kegunaan }\left(\mathrm{Y}_{2}\right) \rightarrow \text { Sikap } \quad \text { Dalam } \\
\text { Membeli Tiket Online }\left(\mathrm{Y}_{3}\right)\end{array}$ & 0,397 & 4,108 & Signifikan \\
\hline $\begin{array}{l}\text { Sikap Dalam Membeli Tiket Online }\left(\mathrm{Y}_{3}\right) \rightarrow \text { Niat } \\
\text { Untuk Membeli Kembali }\left(\mathrm{Y}_{4}\right)\end{array}$ & 0,746 & 15,141 & Signifikan \\
\hline
\end{tabular}
tersebut didapat nilai $\mathrm{Q}^{2}$ adalah sebesar 0,960, sehingga dapat disimpulkan bahwa model memiliki predictive relevance yang baik $\left(Q^{2}=0,960>0\right)$.

Tabel 4.

\section{Path Coefficients}


Hasil analisis seperti yang tersaji pada Tabel 3, menunjukkan bahwa pengujian hipotesis pada pengaruh computer self-efficacy terhadap persepsi kemudahan penggunaan menghasilkan nilai koefisien korelasi sebesar 0,738. Nilai t Statistics didapat sebesar 12,746 (>1,96), maka pengaruh computer self-efficacy terhadap persepsi kemudahan penggunaan adalah signifikan, pengaruh persepsi kemudahan penggunaan terhadap sikap dalam membeli tiket online menghasilkan nilai koefisien korelasi sebesar 0,465. Nilai $t$ Statistics didapat sebesar 5,367 $(>1,96)$, maka pengaruh persepsi kemudahan penggunaan terhadap sikap dalam membeli tiket online adalah signifikan, persepsi kemudahan penggunaan terhadap persepsi kegunaan menghasilkan nilai koefisien korelasi sebesar 0,682. Nilai $t$ Statistics didapat sebesar 10,742 (>1,96), maka pengaruh persepsi kemudahan penggunaan terhadap persepsi kegunaan adalah signifikan, persepsi kegunaan terhadap sikap dalam embeli tiket online menghasilkan nilai koefisien korelasi sebesar 0,397. Nilai $t$ Statistics didapat sebesar 4,108 (>1,96), maka pengaruh persepsi kegunaan terhadap sikap dalam membeli tiket online adalah signifikan, pengaruh sikap dalam membeli tiket online terhadap niat untuk membeli kembali tiket online menghasilkan nilai koefisien korelasi sebesar 0,746. Nilai $t$ Statistics didapat sebesar 15,141 (>1,96), maka pengaruh sikap dalam membeli tiket online terhadap niat untuk membeli kembali tiket online adalah signifikan.

Pengaruh computer self-efficacy terhadap persepsi kemudahan penggunaan, hasil ini sesuai dengan hasil penelitian dari Yusoff et al. (2009) yang dalam penelitiannya membahas tentang penggunaan perpustakaan digital, mendapatkan hasil bahwa computer self-efficacy tingkat tinggi dalam 
menggunakan situs web pada umumnya mengindikasi bahwa seseorang akan memiliki tingkat kepercayaan yang lebih tinggi dalam menggunakan situs web tersebut terutama apabila seseorang tersebut mengetahui bahwa situs tersebut mudah untuk digunakan. Ini juga memperluas kajian Kulviwat et al. (2007) tentang penggunaan komputer, yang menunjukkan bahwa adanya pengaruh positif computer self-efficacy terhadap persepsi kemudahan penggunaan, dimana hasilnya computer self-efficacy ini memiliki peran yang penting dalam membentuk sikap dan kepercayaan diri individu seseorang.

Pengaruh persepsi kemudahan penggunaan terhadap sikap dalam membeli, hasil ini sesuai dengan penelitian yang dilakukan oleh Yusoff et al. (2009), dan Jang et al. (2011) yang dalam penelitiannya membahas situs e-learning, dimana menunjukkan bahwa kemudahan penggunaan antarmuka teknologi dan alat-alat di situs online yang penting dalam memprediksi sikap terhadap belanja online. Secara khusus, penelitian ini lebih jauh berpendapat bahwa konsumen hanya akan mengembangkan sikap yang menguntungkan terhadap belanja online jika situs belanja online yang mudah digunakan.

Pengaruh persepsi kemudahan penggunaan terhadap persepsi kegunaan, hasil ini sesuai dengan penelitian yang dilakukan oleh Yusoff et al. (2009), dimana menunjukkan bahwa adanya hubungan yang signifikan dan positif antara Persepsi kemudahan penggunaan dan Persepsi kegunaan. Hal ini menunjukkan bahwa jika seseorang menemukan bahwa situs ini mudah digunakan, seseorang akan lebih bersedia untuk menggunakannya untuk pencarian informasi. Hasil ini juga sesuai dengan penelitian yang dilakukan oleh Lim \& Ting, (2012) dimana 
hasil penelitian menunjukkan bahwa kemudahan penggunaan antarmuka teknologi dan alat-alat di situs memiliki pengaruh signifikan pada kegunaan konsumen yang dirasakan dari penggunaan situs online.

Pengaruh persepsi kegunaan terhadap sikap dalam membeli, Temuan Alharbi et al. (2014) sebagai studi menunjukkan bahwa konsumen akan mengembangkan sikap yang menguntungkan terhadap produk dan / atau jasa yang dipercaya untuk memberikan manfaat yang cukup atau atribut menuju solusi dan sikap negatif terhadap orang-orang yang tidak memadai. Hasil ini juga sesuai dengan penelitian yang dilakukan oleh Yusoff et al. (2009) dan Suki et al. (2011), yang menunjukkan bahwa persepsi kegunaan secara signifikan berhubungan dengan sikap terhadap belanja online. Sikap positif terhadap belanja online adalah karena alasan bahwa konsumen merasa bahwa belanja online meningkatkan kinerja belanja dan produktivitas

Pengaruh sikap dalam membeli terhadap niat untuk membeli kembali, hasil ini sesuai dengan penelitian yang dilakukan oleh Jang et al. (2011), dan Yunfan et al. (2012), dalam penelitiannya terkait dengan E-Commerce dan produk fashion yang menunjukkan bahwa adanya pengaruh positif dari sikap terhadap minat membeli kembali. Artinya, marketer perusahaan harus mengambil inisiatif untuk meningkatkan niat pembelian kembali tidak hanya berfokus pada interaksi integratif antara persepsi kemudahan penggunaan dan kegunaan, tetapi juga jelas memahami kebutuhan kepuasan pelanggan dan kepercayaan pelanggan. 


\section{SIMPULAN DAN SARAN}

Berdasarkan hasil pembahasan penelitian, maka dapat disimpulkan bahwa implementasi technology acceptance model dalam niat membeli tiket bioskop online adalah sebagai berikut :

1. Computer self-efficacy berpengaruh positif dan signifikan terhadap persepsi kemudahan penggunaan. Artinya, semakin percaya diri seseorang dalam mengoperasikan komputer maka semakin mudah seorang tersebut dalam menggunakan situs MTix.

2. Persepsi kemudahan penggunaan berpengaruh positif dan signifikan terhadap sikap konsumen dalam membeli tiket bioskop online. Hal ini menunjukkan bahwa semakin mudah seseorang menggunakan situs MTix, maka semakin baik sikap konsumen untuk melakukan transaksi pembelian tiket pada situs MTix tersebut.

3. Persepsi kemudahan penggunaan berpengaruh positif dan signifikan terhadap persepsi kegunaan. Artinya, semakin mudah seseorang dalam menggunakan situs MTix, maka semakin besar manfaat yang dirasakan oleh konsumen dalam melakukan transaksi pembelian tiket pada situs MTix.

4. Persepsi kegunaan berpengaruh positif dan signifikan terhadap sikap konsumen dalam membeli tiket bioskop online. Artinya, semakin besar manfaat yang dirasakan oleh para konsumen dalam penggunaan situs MTix, maka semakin baik pula sikap konsumen untuk melakukan transaksi pembelian tiket pada situs MTix tersebut. 
5. Sikap untuk membeli tiket pada situs MTix berpengaruh positif dan signifikan terhadap niat untuk membeli kembali tiket pada situs MTix. Hal ini menunjukkan bahwa semakin baik sikap konsumen untuk melakukan transaksi pembelian tiket bioskop pada situs MTix, maka semakin tinggi pula niat konsumen untuk membeli kembali tiket bioskop pada situs MTix.

Saran yang dapat diberikan berdasarkan kesimpulan yang didapat adalah sebagai berikut:

a. Pihak manajemen 21Cineplex diharapkan selalu melakukan perbaikanperbaikan pada situsnya yang mengarah pada penggunaan yang makin praktis.

b. Pihak manajemen 21Cineplex diharapkan mampu menyesuaikan proses transaksi pembelian tiket pada situs MTix dengan situs beli tiket online lain misalkan dalam proses pemilihan tiket bioskop atau proses pembayaran.

c. Para pengguna yang sebelumnya ragu-ragu untuk melakukan belanja online diharapkan mampu ditingkatkan kemampuannya dari melakukan transaksi pembelian tiket online pada situs MTix, sehingga para pengguna memiliki rasa percaya diri dalam melakukan transaksi belanja melalui situs online.

d. Diharapkan kedepannya pihak Cineplex21 bisa melakukan update pada situs MTix dengan sistem yang lebih baik sehingga tidak terjadi hal yang serupa.

e. kedepannya pihak manajemen 21Cineplex diharapkan untuk memperbarui situs MTix dengan sistem yang lebih baik sehingga para pengguna tidak lagi mengalami kegagalan dalam melakukan transaksi pembelian tiket bioskop online. 
Penelitian kedepan diharapkan dapat menambahkan variabel-variabel yang berbeda yang memungkinkan dapat mempengaruhi niat konsumen untuk membeli kembali tiket bioskop online menggunakan situs MTix. Penambahan variabel ini diharapkan mampu mendapatkan sudut pandang yang lebih luas.

\section{IMPLIKASI PENELITIAN}

Berdasarkan temuan tersebut, maka hasil penelitian ini mampu memperkaya aplikasi konsep Technology Acceptance Model (TAM) dari Davis (1989) yang dikembangkan berdasar teori sikap Theory of Reasoned Action (TRA) oleh Ajzen (1975). Dalam penelitian ini, model TAM dihubungkan dengan variabel computer self-efficacy yang merupakan suatu variabel yang relevan bagi perilaku konsumen akan mengkonsumsi produk berbasis IT.

Saat ini pihak situs MTix sudah memberikan pada penggunanya panduan bagaimana melakukan transaksi pembelian tiket lewat online dengan baik. Kedepannya diharapkan perusahaan mampu melakukan evaluasi dalam memperbaiki panduan yang lebih singkat dan lebih mudah dimengerti oleh para pengguna.

Situs MTix saat ini dinilai sudah cukup fleksibel dalam melakukan transaksi pembelian tiket. Hal ini dilihat dari bagaimana para pengguna bisa melakukan transaksi pembelian tiket pada situs MTix dimana saja dan kapan saja.

Pengoperasian situs MTix sudah dinilai cukup praktis dalam pengoperasiannya. Hal ini dikarenakan saat ini situs MTix bisa dioperasikan tidak hanya melalui komputer atau laptop, tetapi juga bisa dioperasikan melalui smartphone. 
Inovasi perusahaan Cineplex21 berupa pembelian tiket bioskop secara online melalui situs MTix dinilai merupakan suatu ide yang bagus. Hal ini karena jika dilihat dari segi fungsi situs MTix bisa sangat membantu para konsumen dalam melakukan pembelian tiket tanpa harus mengantri.

Dengan adanya situs MTix membuat para calon penonton mempertimbangkan melakukan transaksi pembelian tiket dengan cara manual (antre), karena transaksi melalui situs MTix dinilai singkat, fleksibel, dan praktis penggunaannya.

Keterbatasan yang terdapat pada penelitian ini antara lain adalah sampel pada penelitian ini terbatas pada pelanggan bioskop di Kota Denpasar saja, sehingga hasil penelitian tidak bisa diregeneralisasi di wilayah lainnya, dan data penelitian ini hanya diambil dalam satu titik waktu tertentu (cross section), sedangkan lingkungan setiap saat berubah (dinamis), sehingga penelitian sejenis perlu dilakukan kembali dimasa mendatang untuk mengetahui perubahan perilaku konsumen.

\section{REFERENSI}

Adamson, I. \& Shine, J. 2003. Extending the New Technology Acceptance Model to Measure the End User Information Systems Satisfaction in a Mandatory Environment: A Bank's Treasury. Technology Analysis \& Strategic Management. Vol. 15 No. 54:pp 441-455.

Alharbi, S. \& S. Drew. 2014. "Using the Technology Acceptance Model in Understanding Academics' Behavioural Intention to Use Learning Management Systems". International Journal of Advanced Computer Science and Applications. Vol. 5, No. 1, 2014.

Compeau, D.R., \& Higgins, C.A. 1995.Computer selfeffiecancy: Development of a measure and initial test. MIS Quarterly, 19 (2): 189-211. 
Davis, F.D. 1989. Perceived Usefulness, Perceived Ease of Use, and User Acceptance of Information Technology. MIS Quarterly. Vol. 13 No. 5: pp319-339.

Fishbein \& Ajzen, 1975. Belief, Attitude, Intentions and Behavior: an introduction to theory and research. California: Addison-Wesley Publishing Company, Inc.

Jang, H. Y. \& Mi, J. N. 2011. "Customer Acceptance of IPTV Service Quality”. International Journal of Information Management. 582-592.

Kulviwat, S., Bruner G. C. II, Kumar A., Nasco S. A., \& Clark T. 2007. Toward a Unified Theory of Consumer Acceptance of Technology. Psychology and Marketing 24, 1059-1084.

Lim,W. M. \& Ting D.H. 2012. "E-shopping: an Analysis of the Technology Acceptance Model" Canadian Center of Science and Education.Vol. 6, No. 4; April 2012

Piriyakul, M., Piriyakul, R., Chuachareon, O., Boonyoung, M., Piriyakul, P., \& Piriyakul, I. 2015. "Effects of Trust, Satisfaction and Factors Corresponding to TAM on Intention to Reuse Internet Business Transaction" International Review of Management and Business Research. Vol. 4 Issue. 3: September 2015

Suki, N. M., \& Norbayah, M. S. 2011. "Exploring the Relationship Between Perceived Usefulness, Perceived Ease of Use, Perceived Enjoyment, Attitude and Subscribers' Intention Towards Using 3G Mobile Services". Journal of Information Technology Management. Volume XXII Number 1.

Wibowo, A. 2006. Kajian Tentang Perilaku Pengguna Sistem Informasi dengan Pendekatan Technology Acceptance Model (TAM). Diambil dari: http://peneliti.budiluhur.ac.id/wpcontent/uploads/2008/.../arif+wibowo.pdf, pada tanggal 7 Januari 2012.

Yunfan, L., Yaobin, L., \& Bin, W., 2012. "Effects of Dissactisfaction on Customer Repurchase Decisions In E-commerce - An Emotion - Based Perspective" Journal of Electronic Commerce Research. Vol. 13, No. 3.

Yusoff, Y. M., Zikri, M., Mohd, S. M. Z., Ermy, S. P., \& Emmaliana, R., 2009. "Individual Differences, Perceived Ease of Use, and Perceived Usefulness in the E-Library Usage" Computer and Information Science. Vol. 2, No. 1 